\title{
Transatlantica
}

Revue d'études américaines. American Studies Journal

$1 \mid 2012$

Le roman policier, littérature transatlantique / Maisons

Hantées

\section{The Haunted House in Contemporary Filmic and Literary Gothic Narratives of Trauma}

Monica Michlin

\section{(2) OpenEdition}

Journals

Édition électronique

URL : https://journals.openedition.org/transatlantica/5933

DOI : $10.4000 /$ transatlantica.5933

ISSN : 1765-2766

Éditeur

Association française d'Etudes Américaines (AFEA)

Référence électronique

Monica Michlin, «The Haunted House in Contemporary Filmic and Literary Gothic Narratives of

Trauma », Transatlantica [En ligne], 1 | 2012, mis en ligne le 03 mai 2013, consulté le 31 janvier 2023.

URL : http://journals.openedition.org/transatlantica/5933 ; DOI : https://doi.org/10.4000/

transatlantica. 5933

Ce document a été généré automatiquement le 31 janvier 2023.

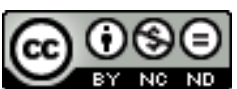

Creative Commons - Attribution - Pas d'Utilisation Commerciale - Pas de Modification 4.0 International - CC BY-NC-ND 4.0

https://creativecommons.org/licenses/by-nc-nd/4.0/ 


\title{
The Haunted House in Contemporary Filmic and Literary Gothic Narratives of Trauma
}

\author{
Monica Michlin
}

\section{Introduction}

1 Haunted houses pervade contemporary American culture: what might have seemed, two and a half centuries ago, a minor motif in a literary subgenre has become, in contemporary popular American culture, a staple of children's literature, a feature of Halloween, a classic attraction of many theme parks, ${ }^{1}$ an established form of tourism, ${ }^{2}$ and a central figure in Hollywood thrillers and horror films alike. Although seemingly traditional narratives still rivet-one need think only of such films as The Others (2001), which takes a classic haunted house plot, and only belatedly reveals its reverse focalization-today's tales of haunting are acutely aware of the haunted house being the psyche itself, as evidenced in popular film by M. Night Shyamalan's TheSixth Sense (1999). In contemporary American literature too, the haunted house motif has endured, from Toni Morrison's beautiful allegory of haunting by the repressed past in Beloved (1987) to Mark Z. Danielewski's extraordinary pastiche House of Leaves (2000). ${ }^{3}$ In this study, I will focus on how the haunted house motif has become prevalent in contemporary postmodern narratives staging the "haunted self" of survivors of trauma, and try to show how these gothic texts or films play on circularity and repetition, blanks and blackouts, fragmentation and incoherence, ${ }^{4}$ both in the character's psyche and in the work's "unveiling" of the truth, so that attempts to put together the pieces of the jigsaw puzzle and to see our way out of the maze-most of these works at least allude to the myth of the Minotaur-are more often than not thwarted. Both clue and decoy, projected symptom and fantastic "reality," the haunted house entraps us and casts its spell, even as we see or read through it. Ultimately, these works play on their being a "haunted house" of images and/or words, keeping us in suspense to the end as to whether there can be either catharsis or exorcism, or 
whether, in an ultimate gothic twist, we as readers or viewers are to be entrapped in haunting without end, in the "ghosting" of the text or film itself, in a form not merely of postmodern Gothic, but perhaps, of Gothic-postmodernism. ${ }^{5}$

\section{The Revival of the Haunted House Narrative in Contemporary American Fiction}

2 Although the Gothic genre did not originate in the USA, it took root there as early as the late eighteenth century; recent studies of Charles Brockden Brown's work in particular illustrate this point. ${ }^{6}$ Nineteenth century Gothic attained classic status more quickly: Edgar Allen Poe's "The Fall of the House of Usher" (1839) is most often quoted as the quintessential haunted house narrative, but "The Black Cat" (1841), might be seen as a darker pre-Freudian deconstruction of wailing ghosts, black cats, and other Gothic symbols as projections of a haunted conscience. Before turning to Freudian theory and to tales of haunting as projective, however, I would first like to explore the works that cast the haunted house as the reflection of a collective, traumatic history.

\section{Cultural haunting and postcolonial minority literature}

3 I refer here to what some have called "cultural haunting" (Brogan, 1998, 4). The exploration of the African-American identity-and other "minority" identities-as invisible (a trope made famous by Ralph Ellison's 1952 novel Invisible Man), and as haunting white America, while allowing "whiteness" to define itself against the black presence (a theory developed by Toni Morrison's 1992 collection of essays Playing in the Dark), has fostered an impressive number of works in which the black voice/presence appears as the return of the repressed, in a counter-text of the taboo past being shattered by the voicing of the unspeakable of the Middle Passage and slavery. The emergence of ethnic minorities' voices shook the very foundations of haunted house literature-Toni Morrison's Beloved (1987) or Gloria Naylor's Mama Day (1988) make it the site of rememory: the traumatic past returns, to force the living and the readers to confront a History of racial violence. Although Beloved is more about haunting than its physical locus, the haunted house is vital to its architecture. ${ }^{7}$ Most contemporary American magic realist and postcolonial stories of haunting, however, do not feature a haunted house per se, perhaps in an enactment of Audre Lorde's famous quip that one cannot dismantle the master's house with the master's tools: Leslie Marmon Silko's Ceremony (1977), Toni Cade Bambara's The Salt Eaters (1980), Cristina Garcia's Dreaming in Cuban (1992), Junot Diaz's Pulitzer-prize winning The Brief Wondrous Life of Oscar Wao (2007), James McBride's Song Yet Sung (2008) feature the voices of the dead, hallucination and dream vision in their rewriting of identity and History as haunted, and as a palimpsest of suppressed voices that return to confront, but also, to protect, both characters and reader. ${ }^{8}$ This literary performance is a revision, through haunting, of official History, but also, of the uncanny as defined by Freud. Indeed, in many of these novels, dead ancestors are often benevolent and protective, in a deliberate reversal of "white" tales of haunting;this reversal can of course be ascribed to the desiredconnection to the dead one has been separated from forcibly. Minority literature, as white literature's "other," often celebrates "the Other Side" or "the other place"-the name given to the haunted house in Gloria Naylor's 1988 novel Mama Day- 
as much as it makes it fearful. But even in minority literature, the haunted house trope is predicated on the house itself having been the locus of familial trauma.

\section{The haunted house as "embodiment" of the Unheimlich}

4 Freud's definition of the uncanny, because it is the negation of the word for "home" (unheimlich), in itself inscribes the home as site and/or source of terror. In its diabolically witty fashion, Mark Danielewski's novel House of Leaves reminds us of the history of commentary on this fact, by quoting Freud (359), but also Heidegger (25), and finally, literary critic Harold Bloom: "Freud himself pointed out that this 'unhomely' might as well be called 'the homely' (...) 'for this uncanny is in reality nothing new or foreign but something familiar in the mind that has been estranged only by the process of repression."' (Bloom in Danielewksi, 359) Recent works like Dani Cavallaro's The Gothic Vision: Three Centuries of Horror, Terror and Fear $(2002,87)$ or Laura Mulvey's Death $24 x$ a Second: Stillness and the Moving Image $(2007,96)$ likewise comment on Freud's word for "uncanny" springing from "home." As Anne Williams puts it in Art of Darkness: A Poetics of Gothic (1995): "English has adopted the term 'uncanny' to speak of this familiarly 'unfamiliar,' the 'un-family-like.' In other words the nightmarish haunted house as Gothic setting puts into play the anxieties, tensions and imbalances inherent in family structures." (Williams, 46) ${ }^{9}$

5 That the home is no sweet home but a dark place, while already implicit in $19^{\text {th }}$ century feminine gothic, or in Henry James's The Turn of the Screw (1898), has been given a new life both in literature and film, in narratives explicitly dealing with childhood trauma due to abuse, in patterns often combining haunted houses and ogre-like fathers, generally depicted as a variation on the mythological Minotaur. Mark Edmundson aptly notes in Nightmare on Main Street: Angels, Sadomasochism, and the Culture of the Gothic (1999):

For Freud, the psyche, however else he may describe it, is centrally the haunted house of terror Gothic. Freud's remarkable achievement is to have taken the props and passions of terror Gothic-hero-villain, heroine, terrible place, haunting-and to have relocated them inside the self.

What haunts the psyche? Its traumatic past, and particularly, the past relations with parents. (Edmundson, 32)

6 If, as Ruth Parkin-Gounelas argues in her 1999 article "Anachrony and Anatopia: Spectres of Marx, Derrida, and Gothic Fiction": "since Walpole's The Castle of Otranto, the genre has remained fixated on anatopias, the repetition of other forms of this house, as well as of its contents: its villains, incestuous relationships, disembodied parts, and above all, the buried secrets of its origins" (131), this "fixation" is in keeping with what haunted houses signify and encode, particularly if it is incest and infanticide. What has changed, as Catherine Spooner expounds in Contemporary Gothic (2006), is that contemporary gothic narratives display post-Freudian awareness that the haunted house is the place where trauma occurred, but also, and subsequently, the projection of the traumatized and haunted psyche itself:

As Emily Dickinson, a poet with a frequently Gothic awareness wrote: "One need not be a chamber - to be haunted": in twentieth century film and fiction, the troubling ghosts of past traumas were not restricted to architectural locales, but made the mind itself a kind of prison. [...] [O]ne of the favorite tropes of contemporary Gothic is the repressed memory of childhood abuse, as in Stephen King's The Shining (1977). Just as Edgar Allen Poe's House of Usher ultimately crumbles into the tarn at its 
foot, so these psychological prisons characteristically disintegrate under repeated mental strain, terminating in madness and breakdown.

In Gothic texts, therefore, the past is a site of terror, of an injustice that must be resolved, an evil that must be exorcised. (Spooner, 18)

7 But how, then, does this contemporary awareness that the house is projective in nature not undermine the gothic text and the fear it creates in the reader or viewer? To work on projection in its many-layered meanings, let us start with film.

\section{Projection, Mise-en-abyme, Reversal: the Haunted Hotel in Recent Film ${ }^{10}$}

At least since Hitchcock's Psycho (1960), the haunted hotel has become the contemporary equivalent of the haunted manor or mansion, in cinema and literature alike. Norman Bates's secret-that he is the hunter, the haunter and haunted, "possessed" by the mother he killed-is of course revealed in the last images of the film, when we hear him talking to himself in his mother's voice, in a case-study illustration of split personality disorder. The hotel itself is real enough, however, as is the Bates house: as Laura Mulvey points out, the film stages the horizontal motel and the vertical (more classically spooky) Bates house, as "split" haunted house, in an announcement of Norman's split self, but also, in an almost literal illustration of the examples Freud originally gave to illustrate the uncanny:

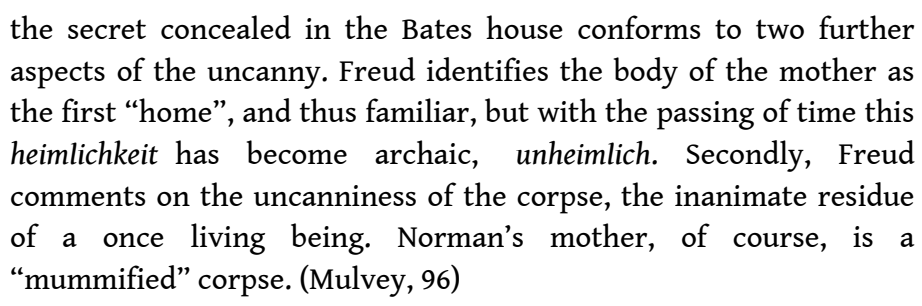

In a slightly less literal illustration of the killer son's haunting being mummy's fault, a recent noir film, James Mangold's Identity (2003), takes the deconstruction of the haunted motel one step further. A dozen characters who do not know each other are forced by a violent storm to spend the night at a nameless motel, only to realize that they are being killed off one by one by an unknown killer-the survivors, led by ex-cop $\mathrm{Ed}$, played by John Cusack, organize to try to find the killer before it is too late. Director Mangold deliberately plays on this scenario being haunted by others: most viewers will have seen Psycho and have read Agatha Christie's And Then There Were None (1940), or seen one of its adaptations into film. When it becomes apparent that no ordinary human being can be committing these murders, we are offered a classic "haunted house" lead-the motel is built on an abandoned Native American graveyard, like the Overlook Hotel in Stanley Kubrick's The Shining (1980). But this proves to be yet another decoy. When the bodies themselves begin to vanish from where they lay, we-like Ed the hero, who, due to stress, in now increasingly subject to migraines and blackouts-feel that we are going mad. In a sudden twist, we suddenly cut to a courtroom, during the same storm we have been experiencing at the motel. To our astonishment, and to his, $\mathrm{Ed}$ is in this room and is told by his lawyer that he is in fact a psychotic inmate, that the entire motel is his own mental construction, and that the various characters are a projection of his multiple selves that he is killing off to "kill the killer inside himself." As Ed/John Cusack is shown his true face in a mirror (a fleshy and bald face that in no 
way resembles him) and reacts in terror, we belatedly understand the clues given throughout the film, from its title (identity), to its opening credits that showed a diary with many different handwritten scripts, to the fact that "Ed" was reading Being and Nothingness when the storm broke. Even as we understand that what we have been watching for more than an hour is the killer's fantasy of repairing his split identity, it is impossible to adjust to the idea that the motel and all the characters we have seen are unreal. As "Ed", the projection of the inmate's ideal self, "returns" to the motel, so do we, in a postmodern play on the "ghostly" and "projective" character of cinema viewing. The posters for the film hint at the true meaning of the title Identity, by showing a hand the various fingers of which are the characters seen in the motel, with the caption "The secret lies within," which plays on the ambiguity of within, the motel not being a "place" but an inner "space" within the psyche itself. ${ }^{11}$

10 In Identity haunting is thus overtly treated as a sustained (psychotic) projection brought on by post-traumatic stress-the killer, like the hero of Martin Scorsese's Shutter Island (2010), has shut out ${ }^{12}$ memories of the crime in which he is both victim and perpetrator. In film, this motif often finds its aesthetic translation in narrative fragmentation, fast cuts, the use of inexplicable glimpsed images of horror, like so many "hallucinations" that recur both to signify and to create uncanny feelings of déjà-vu, the alternating of flashes of light and of deepening darkness to make "seeing through" the dark impossible, and to encode this symbolically.

\section{The war veteran and the haunted house of the hospital}

11 One such haunted male figure, often presented as a "guilt-ridden victim," is the war veteran. From the early mid-90s on, film started to mimic the symptoms of these scarred survivors, whose body and psyche functioned as a haunted house. Adrian Lyne's Jacob's Ladder (1990) remains a paramount example of this filmic mimicking of post-traumatic stress, as we follow a Vietnam vet in two conflicting versions of his return home: one to his blonde family, the other to a gothic brunette. Plagued by monstrous visions, the vet's perspective keeps us jumping deliriously from one narrative line to another, from one "reality" to another, with one particularly atrocious sequence within a veterans' hospital, featuring dismembered bodies and ghoulish figures in the basement, which of course functions as the labyrinth and "dark place" of gothic haunting. Other films about traumatized veterans have followed this aesthetic of psychosis, with a jumbled timeline, twisted montage, strident sounds, and horrible images that make viewing a disturbing or even traumatic experience-most notably Jonathan Demme's remake of The Manchurian Candidate (2004) which revolves around a haunted Denzel Washington whose nightmares are in fact traumatic memories, or John Maybury's The Jacket (2005) in which a Gulf War veteran (Adrien Brody) is subjected to torture in a psychiatric ward that functions much like a haunted castle and which he can escape only through the supernatural straightjacket he is (s)trapped in(to). ${ }^{13}$ In many of such works, if an "actual" house resurfaces, it is later, in the return of the characters, either in body or in spirit, to the locus of the events that shattered them but where they also might find peace at last: both The Sixth Sense and Jacob's Ladder find their resolution in a "stairway to heaven" conclusion: the hero understands that he is dying or dead, and sees himself ascending the familiar stairs inside his home, towards the upper floor; in both these films, much as in The Others, the child as "angel" is the 
go-between guiding the protagonist in his or her migration from the world of the living to that of the dead.

\section{The child, the haunted hotel and the maze in Kubrick's The Shining (1980)}

12 One cannot evoke children and the hotel variation on the haunted house without even a cursory examination of Stanley Kubrick's adaptation of Stephen King's The Shining, which portrays the spell cast by the haunted Overlook hotel on Jack Torrance, a wouldbe writer chillingly embodied by Jack Nicholson. Although the film contains a number of gore images such as the torrents-torrance-of blood cascading down the hotel elevator doors, it makes the haunted hotel an obvious allegory of domestic violence ${ }^{14}$ with the "care-taker" cast as psychopath (even as it reads as a dark satire of the dangers of writer's block). ${ }^{15}$ The film deliberately points to viewing as decryptinghence the hotel's name, the Overlook, which refers both to the view (the hotel is perched high in the Rocky Mountains) and to what we cannot see the first time round. Numerous "messages" are addressed to the viewers, from the word "REDRUM" that "warns" Danny of the impending danger to himself and his mother, to the nightmarish visions behind the door of room 237, to the photographs that we do not quite distinguish on the hotel walls until the very last shots of the film. Terrifying scenes in which the camera follows little Danny, hunched over his tricycle, shooting down the desert hallways of the hotel, in high-angle-shots that suggest something looms over him, play on the corridor as pathway to the "uncanny" and on the feeling that the film, as well as the tricycle, is about to take a "wrong turn."

Danny's mother uses the maze imagery explicitly, when given her initial tour of the hotel-“This place is such an enormous maze I feel like I'll have to leave a trail of breadcrumbs every time I come in" (15')-an image that combines the Little Tom Thumb fairy tale with that of the maze, and warns us that children are at risk in this hotel. This, in turn, draws our attention to the maze-like orange and brown motif on the carpeting Danny cycles on; but especially, to the actual vegetal maze outside the hotel where the chase between ogre-like, axe-wielding father and little boy will take place in the film's final moments. The scene is explicitly heralded: as we see Danny and his mother examining the diagram of the maze posted outside the entrance $\left(25^{\prime}\right)$ and then, walking into it (35') and running into dead ends, we realize that Jack Torrance is at that exact moment scrutinizing the miniature model of the labyrinth in the hotel lounge, towering God-like above it (overlooking it). As he gazes dementedly at a specific location within the labyrinth, the camera zooms back into the actual maze and we find Danny and his mother exactly where his gaze fell, in a fantastic use of montage (35'26) that suggests that he can magically see them as we do, through the camera's eye.

\section{The postmodern updating of the haunted house as body (and of the body as haunted house)}

As opposed to such films as Identity and others that show the haunted house/hotel to be purely projective, The Shining not only casts a "real" haunted hotel, but fits Tony Magistrale's definition, in his study Abject Terrors (2005), of the haunted house as organic: "In most horror films and Gothic novels, the haunted house/castle serves as a 
vehicle for the inner psychology of its inhabitants. The protagonists appear trapped within its recesses especially as the house 'awakens' to assume an infernal biology of its own." (90) The haunted house as "biological" being, or as "body" was the focus of feminist literary and film theory alike, particularly in the 1990s: Julia Kristeva's work on the uncanny in Powers of Horror (1982) spawned "cultural studies" readings of horror film such as Barbara Creed's The Monstrous Feminine: Film, Feminism, Psycho-analysis (1993) and Linda Badley's Film, Horror and the Body Fantastic (1995). The latter shifts interpretations of horror and of gothic representations of the body in particular from the expression of archaic terrors to that of very contemporary anxieties, updating, so to speak, the fear of the "abject" as analyzed by Kristeva, to terror concerning the mutant body in the age of AIDS and other emerging biological threats; and more "coded" fears of post-gendered identities. ${ }^{16}$ As Linda Badley brilliantly demonstrates, by the 1990s, the "haunted house had become the body itself" (6): while the body was increasingly portrayed as mutant (The Fly), cyborg (Robocop), or clone (Blade Runner), haunted houses became "organic," running with blood, excreting vapor or "goo" (Amityville and Poltergeist). ${ }^{17}$ Postmodern and post-gendered configurations of the haunted house-the haunted manor in the cult The Rocky Horror Picture Show with Alice Cooper as transvestite master of ceremonies-displaced the "traditional" haunted house scenario, which increasingly became a subject of comedy and family entertainment (Ghostbusters, Casper, The Haunted Mansion, and, in a spoof on the "dysfunctional" family, The Addams Family).

Because my focus is on the postmodern interpretation of haunted houses, I shall quote Badley's analysis of the haunting nightmare motif as popularized by Wes Craven's cult horror film Nightmare on Elm Street (1984). Badley deftly points out Craven's recasting of the haunted house, and the haunting process itself, as the maze, the nightmare, and the literalization of dreams all combine to create a form of postmodern schizophrenia:

The first film opens as blond Tina is running, screaming, lost, in a dank, steaming maze of corridors and pipes and a stray sheep. This is the boiler room in which Freddy was burned and suppressed. It is Craven's revision of the haunted house and hell into pop psychology's image of the unconscious. [...]

Freddy Krueger-the dream maker or trickster as serial killer and the monster dominating the last half of the 1980s-was also a ghost. As a child molester (and former victim himself) hunted down and burned to death by a group of parents, Freddy was linked with the Gothic "heavy father" figure. [...] Freddy now haunts [present-day children's] shared nightmare, manifesting himself in his victims' "hysterical" bodies. [...]

Freddy was also a descendant of the title character in E.T.A. Hoffmann's "The Sandman," which Freud made the primary text of his famous essay on "The 'Uncanny"'. [...] Freddy's nightmares turned the Freudian dream work on its head, projecting the dream directly onto the screen, involving the spectator in it, and finally validating the dreamer's reality [...] Freddy's nightmares destroyed boundaries between the imaginary and the real, psychology and biology, and raised the specter of postmodern schizophrenia. But as a type of virtual reality suggested through hysterical imagery, Nightmare on Elm Street was also about dreaming and the media as interface. (Badley, 49-50)

While it seems hard for the written word to achieve this almost psychotic illusion that one's worst nightmares are coming true as one dreams them, this is what two postmodern literary works, Jim Grimsley's short story "House on the Edge" (2008) and Mark Z. Danielewski's House of Leaves (2000) achieve, one in miniature, and the other, in encyclopedic form. 


\section{Contemporary Literary Gothic: Circularity, Repetition, Mazes of Words}

\section{The haunting mise-en-abyme of the house of trauma in Jim Grimsley's fiction: The Circle House}

Much of Jim Grimsley's fiction revolves around the abuse of children in poor white Southern homes. His first novel, Winter Birds (1994), explicitly deals with the family cellas lethal, and casts the culmination of trauma in a house-the "Circle House"-that resurfaces in two later works, Comfort and Joy (1999), the sequel to Winter Birds, and the short story "House on the Edge" in the 2008 collection Jesus Is Calling You. The story deliberately plays on intertextual echoing of Winter Birds and on the haunting of the narrator by a horrific dream about a surreal house-maze-tower of terror. Winter Birds' eight-year-old Danny is, like Grimsley himself, a hemophiliac, living in a house where beatings inflicted by his violent, alcoholic, one-armed father, are the norm. From the first paragraphs of the novel, the father is introduced as a Minotaur-like figure through the connotations of the thread and animal imagery deployed: "From the house you hear the sound you have come to escape... From it travels a flat thread of sound, and you feel yourself go empty listening to it. 'It's Papa', you say. A raw edge to the wind's flight above the fields, a sound like an animal would make." (3)

The disquieting choice of the second person-"you"-throughout the novel initially leads us to believe that the narrator is addressing a dead sibling, but the addressee is himself. Indeed, in the last pages of the novel, the child he was"dies" in a traumatic scene of sexual abuse, the specifics of which are blanked out by an ellipsis. This blank can be read as a figuration of the trauma itself: a gaping hole, a wound that cannot be healed, something unspeakable, to remain-markedly-untold. These images of the "hole" or "gash" are all the more relevant in the case of sexual abuse, but such imagery saturates the text from the start, due to the fatal combination of a gothic father, Dan's hemorrhages and comas: his body is itself a vulnerable house, as the phrase "you are happy you have no hurt places on you today" (3) illustrates. The Dan who narrates can only speak of/to the child he was before the trauma as "other," in a gothic enactment of Rimbaud's famous quotation on autobiographical narrative ("je est un autre") and as an aesthetic performance of trauma as dissociation. Readers can also take this "you" to be addressed to them, which raises the possibility, on another level, that our own story is being told to us: that this may also have happened to us, but that trauma has shut the memory out. ${ }^{18}$

The structure of Winter Birds is a time-loop, from first page to last, to a Halloween-like night of ...Thanksgiving, in a home of circular design, which appears eerie from the moment Danny and his sister Amy first lay eyes on it:

This is the seventh house you have lived in since you were born. After you move out of this house, you will live in seven others with your family. (18)

Aloud, Amy said, "You could run around this house forever, and forever, and never get caught, Mama. Did you hear that part? The doors make a circle, and the rooms go round and round. Papa can't catch you in here." (87) the center of a circle of homes, under the sign of the magical number seven. While 
Danny's sister reads into the circle the promise of escape, the wheel proves that of bad fortune. When on the fateful night, their father, wielding a butcher knife, hunts them down from room to room, Danny recites the magical unpunctuated formula of pure flight: "You think kitchen to bedroom to bedroom to living room to kitchen. Perfect circle of doors." (181) But as he runs, his perspective slants into the desperate italics in which the circle now seems the "evil eye" of fate or of his father's omnipotence: "The circle is a wheel, you are under the center, the hub is an eye looking down at you when you look up." (182) The fairy-tale mode which accompanied the first depiction of the house now turns gothic: no longer a magic circle, but a dungeon the child can never escape from, in a permanent present of trauma, where past and future dissolve into endless repetition:

You will live in it only for the one winter. But you will remember this house better than any of the ones that come after it, and in your dreams you will pass many times through the circle of doors, watching the light fall through the windows, hearing your Mama walk from room to room as if rehearsing her path. (88)

21 This combination of flashback and flash-forward, of the prophetic mode and of retelling, of images of initiation (passing through the circle) and of violation of the taboo, of anticipation of the gothic threat and of "rehearsal" of escape, is reinforced by the haunting in dreams to come: "and maybe some of your memories are only dreams of other nights; maybe when you are sleeping you can feel all nights, past and present, stretching ahead and back for many years." (191)

In the sequel to Winter Birds, Comfort and Joy, Dan returns to the house, with his lover, in search of closure. The house is explicitly depicted as decrepit and haunted by his memories-Dan mentally addresses it, in uncanny personification, as he steps onto the porch: "Do you recognize me? Did you think I would ever come back?" (120). Although much of the novel concerns the struggle between trauma and hope, it is, essentially, an optimistic gay love story about the healing power of love. In Grimsley's latest opus, the short story collection Jesus is Sending You This Message-a title which rings with Flannery O'Connor-like ironies-the Circle House nonetheless traumatically resurfaces, in the story "House on the Edge."

\section{The Circle House returns as maze in "House on the Edge" (2008)}

23 From its threshold ("In the dream..."), "House on the Edge" imprisons us within a nightmare-and within this nightmare, inside a circular house of fantastic proportions:

I can feel a whole house around me, rising up a hundred floors above and descending a hundred floors below, so that I share in equal parts the house's emptiness and weight [...]. A wide corridor runs down one way and turns, and runs down the other way and turns, so that the door to my room is in the middle, the only door here. (27)

While the word "runs" already suggests the necessity for flight and escape, the narrator suggests that the topography of the house itself is impossible to master: "Though I heard once, when people still lived here, that the halls all run in a wide circle, that there really is only a single hall, running upward in a spiral so vast that one can feel neither the curve nor the grade." (30). As an "uncoiling" of the circle, the spiral suggests danger, as in the expression "spiraling out of control"; like the labyrinth, or maze, it symbolizes the collapse of time, space, and identity. Within this maze, in the "daytime" of the dream, the narrator roams like a ghost, in a hopeless quest for escape: 
"During the day I roam. The house is vast, is on the edge of something. I long to get out, I search, I try for exits but find only corridors, endless stairways, rows of bare windows that won't open" (29). The house itself changes shapes surrealistically, like an Escher staircase: ${ }^{19}$

sometimes I can feel the wind get in through a hole somewhere, and look for it, but never find it. Somewhere is a gash in the outer wall a hundred yards wide. I saw it years ago. If I could go back there now I would jump out of it, but I might wander for years and never find it. The house shifts shapes at night, the house is shaped like the wind. (30)

The gash imagery echoes the narrator's fear of violation ("a hole"); night-times he stays locked inside his room to escape the ogre-like monster, a "he" described as "something not human" (30), that taunts him perversely: "Would I hurt the pretty Dan? Would I cut his pretty throat? Would I?" (31). The "sh" sound, in "gash," "shifts," and "shapes" mimics the sound of the wind tearing through house and text, combining sibilance and hushing, foregrounding the aesthetics of blanks, ellipses, and fragmentation. The fear of violation is emphasized too by the trope of the "ruin"-"The house is all waste. Some disaster has happened, some war, perhaps, all the lower floors are ruin." (30)-which reads as a metaphor of rape (Danny as "ruined boy" in Victorian use of the term, the "lower floors" as an image of the raped body). Metatexually, the ruin is a mirror-image for this text, undermined by indeterminacy ("some", "perhaps"), so as to lay waste to all but the "foundations" of reading itself.

Given that Grimsley is an acclaimed writer of science fiction, one might read this short story as a post-apocalyptic fantasy, featuring collective ruin and trauma, much like Octavia Butler's Parable of the Sower (1993), Michael Cunningham's Specimen Days (2005), or Cormac McCarthy's The Road (2006), to name but a few-novels that fit Ronald Granofsky's definition of the trauma narrative. ${ }^{20}$ Grimsley's story instead portrays an already-ghosted collective trauma, in a dream within the dream: "The first time he ever tried to pick a lock where I slept I was dreaming the dream: the halls teemed with invisible men and women, none of whom could see each other, all fleeing from the same man." (29). But, like the house itself, all Danny tells us is perpetually shifting shapes ${ }^{21}$ within a rewriting of the Minotaur myth, with Danny as sole survivor in a vertical, rather than horizontal, maze.

Although the story ends on an awakening-“The door begins to open and I see him at last. Here I wake." (31) -, there is neither catharsis nor release:

But there are times yet worse, times like tonight, when the dream door swinging open is my own, when the empty house I wake into is this one. I can see him at the door, his blue eyes glowing-this is not a dream any more, but I can still see him, can even hear his breath, heavy and forced. For a long time he looks at me. But at the end he only smiles, derisive. There is unfinished business between us. (32)

The hypnopompic continuation of the dream, and the assertion "this is not a dream any more" point to psychotic hallucination, or to the reliving of trauma in dissociation, while the phrase "there is unfinished business between us," which plays on the analogy between reading and dreaming as the story draws to a close, leaves us similarly on edge, haunted by haunting, like doubles of the narrator himself.

The deliberate and obsessive repetition of themes of abuse and trauma from Grimsley's first opus to his latest creates a haunting within the work itself, through the nexus of images that brutally resurface, or shimmer on the edge of one's memory, precisely because they are shifting variations from the earlier writing, returning in disguises that 
make recognition all the more traumatic. Just as the time-loop and dream-reality continuum enacted in "House on the Edge" are variations on the nightmare scenes of the Circle House depicted or suggested in Winter Birds decades earlier, so the monster marks the return of the monstrous father. The narrator of the story denies this even as he recognizes it, reversing the mechanisms of projection and recognition at work in traumatic memory-"Sometimes I think he looks like my father, though that is only my imagination" (31) - but his description of the monster's feet-"bare, white as snow, and the toenails were ragged, gray" (31)-echoes, word for word, the abusive father's in Winter Birds: "the nails gray and raggedy-edged because he does not cut them but waits until they are long enough to tear with his fingers" (95). As for the monster's voice, it resembles the "crying wind" (27)-again, a ghostly recall from The Winter Birds, of the father's cry which lends "a raw edge to the wind's flight above the fields." The synesthesia "the voice has teeth that rake my spine" combines an image of horror-the etymology of which is "the bristling of hair on the nape of the neck" Twitchell, 1985, $10)^{22}$-and the image of hunting (the predator's teeth scraping at the prey's fleeing spine) in a gothic crescendo. Thus does Grimsley's work over the years reflexively build up a haunted house of trauma through the aesthetics of repetition, gradation, synaesthetic images of pain, but around a "voided" center, the initial trauma having been erased, much like the empty middle of the surrealistic staircase.

\section{The "queering"23 of Southern Gothic: haunted Houses, trauma and maze in Grimsley's Dream Boy (1995)}

This literary representation of the haunted house of trauma takes on extra depth if one has read Grimsley's earlier novel Dream Boy (1995), which features a mise-en-abyme of sexual violence, trauma, and finally, death through gay-bashing in a haunted house. Nathan, a boy who has been raped by his father in the past, but who has fled his home and found some happiness in a secret romance with a local boy, Roy (his dream boy), experiences déjà vu as he, Roy, and some of the latter's redneck friends make an outing to a local haunted house. Nathan is disquieted by the "eerie familiarity" of the road (128); when the house appears, "something prickles in the image, as if he already knows the place" (129). Images of the journey back towards past trauma ("The signs of damage are old; this did not happen last night," 135) point to the nodal aspect of the gothic haunted house: the place of conflation between past and present, self and uncanny other, past and present trauma, much as they do in "House on the Edge." The haunted house is equated not with terror of "other" ghosts, but with Nathan's sense of absolute doom: "The emptiness beckons him, as clearly as if it is calling his name. Again comes the sensation that the passage of time has been slowed or stopped. That he will never leave this darkness." (141).

When the ghost appears, the text introduces the maze imagery-"there are two of Nathan, moving in different directions, and time is no longer a line but a knot, a maze, through which he must pick his way" (161)-which announces the emergence of the "monster": "But it is a thing even if it is a man, and Nathan is afraid of it, because it is as if it has always been waiting for him, as if it always knew he would come." (167). In a supernatural twist, although Nathan is raped and killed by Burke, one of the other teenagers, Roy having fled, a vision of love at the precise moment of his ghosting makes him rise from the dead: "It is like a vision from some time in the future, or like 
something out of a dream" (178). Resisting the engulfing maze of the mansion-"He has the feeling he could wander here, for a long time, so he is very careful to keep his bearings" (181)-Nathan finds his way out of the haunted house and back to the town. The merging of gothic strain and that of Christian resurrection makes Dream Boy, as Ed Madden (2000) and David Jarraway (2000) have respectively analyzed, a unique haunted house narrative turning "Southern gothic" into "queer Gothic" and even, "queer gospel." The title of the novel, dream boy, suggests that only the amazing grace of love can conquer the maze of haunting; but the fragmentation of the narrative from the moment Nathan dies suggests that perhaps he only rises from the dead in our dreams, or that there are indeed two of him (the name Nathan is, relevantly, a nearpalindrome).

\section{Maze imagery and the self as "House of Many Souls" in Matt Ruff's Set This House in Order (2003)}

In Matt Ruff's Set This House in Order (2003), the process of "shattering" and fragmentation we have seen in Grimley's fiction is reversed. We start with fragmentation and the image of the self as house of many souls: in the opening pages, the narrator, Andrew Gage, explains that, in the wake of his stepfather's abuse, he split into many "souls," many of which shattered in turn; and that his "father"-a mental projection, since Andy's real-life father is long-dead-built a house for these selves to survive:

[M]y father worked to establish order. In place of the dark room, he constructed a geography in Andy Gage's head, a sunlit countryside where the souls could see and talk to one another. He created the house, so that they'd have a place to live; the forest so they'd have somewhere to be alone; and the pumpkin field, so the dead could be decently buried. (2)

By playing on the quotation from John 14:24-“'In my Father's house are many mansions: if it were not so, I would have told you. I go to prepare a place for you"-and on Isaiah 38 ("Set your house in order, for you shall die, and not live"), the beginning of the novel already implies that Andy lives a "haunting" by multiple personality disorder, ${ }^{25}$ and that the house set in order is that which the reader enters as she or he cracks open the book. Although we know that for the outer world there is only one Andy, each of these personalities has such perfect pitch of "voice" (shy, belligerent, protective, etc.) that it is difficult to think of them as "fragments"; we come to think of them as autonomous characters. By forcing us to accept Andy's performance of multiple identities, Ruff sets us up for a shock concerning Andy's body, which is only revealed (by another character's gaze) midway through the novel. To complicate the representation of the self as haunted house, Andy meets Penny, another "multiple" as he puts it, and one terrified by the "others" within her head. Consequently, the narrative plays on the different modes of representation of the split self, and translates all of the symptoms-memory loss, blackouts, hallucinations, mood swings, sudden terror-into their literary equivalent: incomplete flashbacks, ellipses, hypotyposis, sudden changes in voice and register, depictions of alien, dark, settings... Penny's more demonic "selves" are given Goth names (Maledicta, Malefica) to emphasize the allegorical haunted house structure, while the most submissive is called Mouse. (Maledicta and Malefica are, of course, twins). The obvious correlation between multiple personality disorder and literary creation-what is a "multiple personality" if not a 
talking book of many characters?-allows the perfect mirroring of haunted house, and house of fiction.

Set This House in Order, like many of the works analyzed here, identifies the haunted house of fiction with the Minotaur myth as well. Although House of Leaves (2000) demonstrates that within the haunted labyrinth, the Minotaur can be identified in complete ambivalence as the monster, and/or the victim-the abused child abandoned by a rejecting father, becoming a monster in turn, much like Dr. Frankenstein's unnamed creature turned "monster" through rejection-most works clearly identify the abused child as prisoner, and the abusive parent as Minotaur. ${ }^{26}$ Set This House in Order is no exception to the rule: when Penny undergoes hypnosis for her "selves" to emerge, she sees herself as "Mouse" at the mouth of a labyrinth, and discovers the personality ("Thread") that can lead her out. Although these images of the labyrinth of the inner self and such onomastics as "Mouse" and "Thread" may seem heavy-handed to the sophisticated reader, the novel does turn the "haunted house" landscape into an original, purely projective, maze.

\section{The Ghosting of the Text Itself}

\section{The Labyrinth of House of Leaves (2000)}

As Dani Cavallaro reminds us, beyond its symbolic meaning as dark place of terror, the labyrinth is also an image of the complexity of the literary text $(2002,30),{ }^{27}$ in a mirroring between Gothic's themes and the literary forms it gives birth to:

Gothic figures of fragmentation, disorder and excess are frequently mirrored by textual bodies that reject organic unity in favour of a multiplicity of viewpoints and styles, pastiche, collage, and quilting. These provide a representational correlative for the polymorphousness of fear itself. (Cavallaro, 2002, 211)

From this metatextual standpoint, few haunted house stories are as challenging or as original as Mark Z. Danielewski's stunning postmodern metamorphic construction, House of Leaves (2000). An extraordinary pastiche of genres, from stories of haunting to epistolary novels to autobiography to academic research, the novel is a palimpsest of texts and (narrated) film. At the core of the novel is a manuscript by a blind erudite, Zampanò, who dies leaving a manuscript about a documentary film, The Navidson Record. Zampanò's manuscript is annotated in turn, in another font and another series of footnotes, by Johnny Truant, ${ }^{28}$ a tattoo artist who gradually becomes haunted by what he reads of Zampanò's text; this manuscript in turn is commented by unidentified editors of the entire text, who have added documents and appendixes at the end of the book. The documentary at the heart of the text, The Navidson Record, is a high-culture variation on the cult horror film The Blair Witch Project (1999)-a famous photographer discovers that his house is haunted, and films his "explorations" of it. In a telescoping of myths, Danielewski imagines that the house is haunted by an "inner space" that appears in the form of a mysterious corridor that expands into infinite forms-a spiral staircase, a multitude of corridors and rooms-and which can be defined as a proteiform maze. Just as the house indefinitely expands, deconstructs and reconstructs itself, without its exterior dimensions changing at all, so the text keeps expanding and deconstructing itself through the ironic use of footnotes between its front and back cover as outer "walls." The footnotes offer multiple, and conflicting interpretations of the house and of the photographer's desire to explore and film it, turning the entire 
book into a parody of academic research, expounding theory after contradictory theory, quoting sources that range from celebrity magazines to fictitious scholarly writings, to real essays in philosophy and other works. A tongue-in-cheek pastiche of philosophical enquiry, an exhaustive exploration of the myths of the labyrinth and the Minotaur, a (de)construction of representation in all media from film to photography, to collage, to poetry, and prose in its many genres, House of Leaves is a reflexive creation of the haunted house.

The title can only be understood in polysemy, as the house of disappearances ("Alas to leave. For this has all been a great leaving. Of sorts. Hasn't it?", 510), but also, that of leaves of paper. Where Grimsley's Danny could only state that the house he was in changed shapes, Danielewski's house of leaves and words mimics these changes in pages 424 to 489, devoted to Navidson's "Exploration \#5": the layout on the page suddenly matches the meaning of the text, in calligrammatic style. For instance, a narrowing corridor is materialized by an increasingly small "blocks"-paradoxically signifying hollow tunnels-of words in the middle of an otherwise blank page (433-60), in which words themselves are squeezed out of shape. Page 446 only has this block of words at the center of the otherwise blank page:

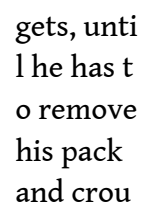

38 The end of the word "crouch" comes on the next page (447), forcing us to feel the "crunch" as the haunted space the character is exploring contracts still further:

$$
\begin{aligned}
& \text { ch. So } \\
& \text { on he } i \\
& \text { s on all } \\
& \text { fours p }
\end{aligned}
$$

39 Similarly, when Navidson climbs up a ladder, we discover a "ladder" of words we are made to read vertically, from bottom to top (440-41). Disorientation is forced upon us by the sudden appearance of diagonal lines of text (464-65), or lines written upsidedown (480: "don't be afraid"). This last paradoxical injunction simply highlights the dark humor in the literary performing of terror and of haunting, evident from the first "ghostly" appearance of the word house. Font color is of course part of these techniques: the core of the text that revolves around the Minotaur is in red linedthrough font, so as to be horrific (red connotes blood and human sacrifice) and ghosted, since it is paradoxically "struck" into (taboo, unspeakable) existence, even as it seems struck out (marking its status as prohibited, not erased).

Chapter IX, devoted simultaneously to Exploration \#4 and to the Minotaur, is the most remarkable in its metatextual games and enactment of reading as an exploration process, for instance in footnote ${ }^{139}$, page 115: "If one reads too quickly or too slowly one understands nothing," which itself is extended by footnote ${ }^{135}$, which sends one back to page 138-i.e., the page before page 139, in an image of reading from the end back to the beginning. This note aptly reads:

\footnotetext{
or in other words, like the house, the film captures us and prohibits us at the same time as it frees us, to wander, and so misleads us, inevitably, drawing us from the us, thus only in the end to lead us, necessarily, for where could we really have gone?, back to the us, and hence back to ourselves.
} 
41 This metatextual assertion clearly identifies watching the/a film and being lost in a labyrinth; a labyrinth of the self, and of imaginary projection ("for where could we really have gone?"), which reading and writing are simply another version of: the entire sentence in lined-through red is obviously a meandering, labyrinthine sentence that leads us back to ourselves, reflexively, as the sentence closes. Rather than reading the red "line-over" as simply a "striking-out" of the taboo manuscript, one must also see it as the "line" out, back to one's starting point: an Ariadne's thread spooling into, and out of, the labyrinth of each reader's mind and psyche.

Other metatextual comments abound, such as Johnny Truant's wry “dark languages rarely survive. As quickly as they're invented, they die, unable to penetrate much, explore anything or even connect." To appreciate the multiple puns on "penetrate" and "connect", one must bear in mind that this comes just after a description of a sexual climax in werewolf-like-lust; that the various films of the house are all entitled "Exploration" so that the "act" of reading is similarly seen as only making ephemeral connection with meaning. And as one reads the exploration of the house, footnote ${ }^{144}$ opens up in a blue-framed window top right of the right page (page 119), to give an inventory of all the amenities present in a house but absent from the maze. This surreal inventory, which includes brand products unidentifiable except for the do-it-yourself wiz, continues within a similar "window" on every odd-numbered page until page 141, where the inventory ends and the comment in red appears: Picture that. In your dreams, simultaneously ordering representation and its impossibility-or, more deviously, its surrealistic possibility... in dream-form. Meanwhile, all left-hand pages contain the text of the page before, as if it had seeped through the paper (these boxes are thus unreadable, since they are in "mirror-writing." Once the inventory is over, a white box on page 143 is "translated" into its reverse (a solid black box) on page 144 and then "widened" into a blank in the text on page 145, in an expanding series of visual, iconic as well as textual jokes as to the house being just words, paper and ink.

43 House of Leaves is the haunted house book to end all haunted house books, one might feel, since it manages to include avatars of the classically gothic place of haunting in one of its appendices-the letters sent by Johnny's mother, who was locked up in a mental asylum when he was a child. These letters are themselves a labyrinth of sorts, in classic feminine Gothic mode, since they make it impossible to determine if Johnny's mother is mad, or if, as she believes, she too is being haunted by a darkness that preys upon her. It is equally impossible to determine if she was a monster or a victim in Johnny's traumatized childhood, before and after she was committed to the asylum: page 517 completely revises the version of the past given page 629, which we have read before, a footnote having (in perfectly mad fashion) sent us to pages 586-643 long before we reach page 517. A coded letter, which Danielewski leaves it up to us to decipher, after giving us the key, points to the meanings within meanings, creating a paranoid universe of monsters that appear only to disappear-thus, in footnote ${ }^{390}$, Johnny tells us of a nightmare in which he obviously is the Minotaur, about to be killed by Theseus (403-06).

44 Amusingly enough, it seems that Danielewski does not quote the work that inspires this dream narrative, Borges's short story "La Casa de Asterion" (1947), a poignant rewriting of the Minotaur myth seen from the perspective of the Minotaur. This is absolutely in keeping with Danielewski's not quoting The Blair Witch Project (1999) either -thus ghosting some of his main "primary texts" while paradoxically inflating the 
footnotes with absurd inventories of useless references. For instance, footnote ${ }^{147}$, which takes the form of a column on the far left of every left-hand page from page 120 to page 134 enumerates all the architectural styles and actual buildings the house bears no relation to, and ends on the tongue-in-cheek comment: "which is also a good place to end though of course it cannot end there either ${ }^{147}$ "... Then footnote ${ }^{147}$ starts all over again, in reverse, on every right-hand column of every right-hand page, in upside-down writing, as if in "rewind" all the way from page 135 back to page 121 to quote every famous architect that comes to mind. One could of course argue that the book seeks to drive readers mad, since it is only just "readable" (it falls under the heading "ergodic literature" for the work it requires); but it is obvious that these absurd academic footnotes construct a house in a double column of words that are "neither here nor there"-another definition of ghosting. As for Danielewski's mise-en-abyme of images of the maze, which resurface everywhere including in Johnny's very body, from the scars he bears on his arms ("whirls of melted flesh," 20), to his "labyrinthine brain" (51), to his ears ("the inner labyrinths hidden deep within our ears," 89), it attempts, beyond postmodern reflexive humor, to "tattoo" the labyrinth into us, to force us to internalize the house and make us as vulnerable-as thin-skinned-as Johnny and his mother Pelafina. ${ }^{29}$

When, in a metalepsis, Johnny confides that he is starting to suspect that his narrative is not his own, the ghosting comes full circle:

forcing me to face the most terrible suspicion of all, that all of this has just been made up and what's worse, not made up by me or even for that matter Zampanò.

Though by whom I have no idea. (326)

Danielewski's brilliant play on the ghosting of the author-what is the " $\mathrm{Z}$ " in his own name, if not the ghosting of "Zampanò"?-and inset narrators alike echoes his trickster's use of intermediality ${ }^{30}$ and his "narrating" an inexistent film in everything from calligrams to mock interviews, to entire pages of the film's dialogue, in what is possibly the world's longest ekphrasis. One that is paradoxically turned back into images, through the use of calligrams-and even, perhaps, into a "mentally reconstructed" form of cinema. For instance, when one door after another slams shut in the labyrinth (217-224) and only one word appears per page, from page to page, to performatively narrate this, the single word per page creates the impression of a Dolby surround sound effect of doors slamming left and right.

Yet Danielewski's tour de force ultimately points to how film and literature do not represent haunted houses with similar means, simply because film can more literally play on darkness, overexposure, violent images forced in rapid succession upon our eyes in violent jump cuts or in violating close-ups; it can operate like the rape of the gaze, by imposing that which we at the last minute would rather not see, in ways that no book does-few people scream with terror even when reading a terrifying ghost story. By focusing on the terrified character's gaze onscreen while we are plunged in the dark, cinema builds up identification in ways that literature can only imitate; we see terror in the victim's pupils before we see the object of terror itself. Cinema invades us through our sense of hearing too, making us vulnerable to suddenly squeaking doors, sighs or whispers, screams or spooky music. In contrast, literature can only use words, even when in metaphorical imagery, synaesthesia or calligrams. ${ }^{31}$ 


\section{Words, words, words... ghosted into nothingness}

And yet, words offer endless poetic games on the ghosting of the house of fiction itself -an emblematic example is Scottish author ${ }^{32}$ Ali Smith's Hotel World (2001), which won a number of awards and was short-listed for both the Orange Prize and the Booker Prize in 2001. The novel begins with the voice of a teenage girl who fell to her death in the dumbwaiter, just after having started to work as a hotel chambermaid. The ghost expresses herself in deliberate paradoxes-"now that I'm nearly gone, I'm more here than I ever was"-and sarcastically ("haha") comments the cliché about the dead being "silent forever" (5), conscious as she is of her own wordiness. Hers is a deliberately histrionic voice that quotes Hamlet's famous "words, words, words" ${ }^{33}$ (6). When she says "I will miss my fall that ruined me, that made me wooo-/hooooo I am today" (8), this carries echoes of the exhilaration of a roller-coaster ride, but is also an amusing pun on ghostly identity, since "hoooo" is the traditional groan of ghosts and since it is also a pun on "who I am today." The same puns on being a "spook" are apparent in her speaking of her story as "a shadow-story" (8). Though the ghost displays a form of teenage cynicism, she also expresses a tragic consciousness of disappearing completely. Indeed, the self-address "Hurry up [...] The colours are going" (7), signals this process of ongoing loss.

eyond her lost senses, the ghost is losing the very signifiers that describe/conjure up the world. As she reaches for the cliché "birds' beady eyes" (8), the word "eyes" evades her-the double periphrasis "The things they see with. The things we see with," and the narrator's desperate attempts to retrieve the term, make the absence of "eyes" even more... glaring. The metatextual comment "the word's gone", and the insistence that this process of obliteration is happening in real time ("I had it a moment ago," 8), create anxiety inasmuch as this vanishing is taking place before our very eyes. A similar effect of disquieting strangeness is brought about by the periphrasis for human eyes, described as being "stuck in a face above a nose," which announces the even more obviously gothic definition: "in people they're small holes surrounded in colour" (8). This off-color image is reflexive of the hole language itself seems to be falling into: there is a surrealistic, Alice-in-Wonderland aspect to this play on holes and vanishing. There is of course a deeper logic to the "suppressed" terms: the true meaning of the loss of "eye" may be the pun on "I," and the vanishing of self. The text is that hotel from which the character, real and unreal, material and immaterial, cannot escape. The hotel world is the world of words: it is "nothing but air" itself; but any voice that arises from the page can "touch" (6) us. The performative reality of narrative, which by telling, creates, is reversed here into the paradoxical creation of erasure, the opening up of blanks. There is an obvious joke in creating a ghost who quotes Hamlet, thus alluding to the most famous ghost in English literature as well as to the most famous soliloquy, the celebrated "To Be or Not To Be" which would so aptly apply to our narrator.

\section{Conclusion}

If haunted houses have endured in recent American literature, authors and directors have had to find new variations on a now classic gothic motif. From tales of haunting that deliberately shun the house for larger settings, to attempts to renew the topos from

Transatlantica, 1 | 2012 
a psychoanalytical perspective, presenting it as a projection, double, or embodiment of the haunted psyche itself, the haunted house narrative haunts on. Both cinema and literature can play on the mise-en-abyme of haunting, in literal darkness and projected nightmares in the movie-house, or in the use of dream-vision, palimpsest and echoes of other tales or imagery of haunting present in the reader's subconscious. Whether through reversals in perspective in The Sixth Sense or The Others, a play on hallucinations in Identity, or the (de)construction of the house of haunting in Set This House in Order, "House on Edge" or House of Leaves, most of these works play on dreamnarrative, palimpsest, and ghostly intertext. As they do so, they explicitly refer to images of the maze and of entrapment without end. The most sophisticated of these works imply that we cannot enter these haunted houses without running a risk, for even as the literary or cinematographic sleights of hand are revealed, the haunting continues on another level, whether through a subtle use of déjà vu (for readers of Jim Grimsley's fiction) or through the "ghosting" of the medium itself (words disappearing from the very text of Hotel World). That contemporary postmodern gothic is more selfconscious and more sophisticated than ever before (Spooner, 23) ) $^{34}$ does not make it any less terrifying, quite the contrary. Whether we see today's works as the triumph of postmodern Gothic, or, as Maria Beville does, of Gothic postmodernism, ultimately, the haunted house narrative must simultaneously make us feel that we have come home to our deepest terrors and that we are trespassing into thrillingly forbidden territory: in the words of Houseof Leaves'sparadoxicaldedication, it must tell us, as we attempt to cross the threshold of the liminary page, This is not for you.

\section{BIBLIOGRAPHIE}

AMFREVILLE, Marc, Charles Brockden Brown, La part du doute, Paris, Belin, 2000.

---, Écrits en souffrance. Figures du trauma dans la littérature nord-américaine, Paris, Michel Houdiard, 2009.

BADLEY, Linda, Film, Horror and the Body Fantastic, Contributions to the Study of Popular Culture, number 48, Westport CN, Greenwood Press, 1995.

BEVILLE, Maria, Gothic-Postmodernism: Voicing the Terrors of Post-Modernity, New York, Rodopi, 2009.

BROGAN, Kathleen, Cultural Haunting: Ghosts and Ethnicity in Recent American Literature, Charlottesville, Virginia UP, 1998.

BUSE, Peter and Andrew STOTT eds, Ghosts: Deconstruction, Psychoanalysis, History, New York, Macmillan Press, 1999.

CAVALLARO, Dani, The Gothic Vision: Three Centuries of Terror, Horror and Fear, New York, Continuum, 2002.

CREED, Barbara, The Monstrous-Feminine: Film, Feminism, Psychoanalysis, New York, Routledge, 1993.

CURTIS, Barry, Dark Places: The Haunted House in Film, London, Reaktion Books, 2009. 
DANIELEWSKI, Mark Z., House of Leaves, New York, Random House, 2000.

DERRIDA, Jacques, Specters of Marx. The State of the Debt, the Work of Mourning and the New International [1993] (Transl Peggy Kamuf), New York, Routledge Classics, 1994.

EDMUNDSON, Mark, Nightmare on Main Street: Angels, Sadomasochism, and the Culture of Gothic (1997), Cambridge, MA, Harvard UP, 1999.

EGAN, Jennifer, The Keep, New York, Alfred A. Knopf, 2006.

FREYD, Jennifer J., Betrayal Trauma: The Logic of Forgetting Childhood Abuse, Cambridge, MA, Harvard UP, 1996.

GRANOFSKY, Ronald, The Trauma Novel: Contemporary Symbolic Depiction of Collective Disaster, New York, Peter Lang, 1995.

GILBERT, Sandra M. \& Gubar, Susan, The Madwoman in the Attic: The Woman Writer and the Nineteenth Century Literary Imagination [1979], New Haven, Yale UP, 2000.

GRIMSLEY, Jim, Winter Birds [1992], New York, Scribner Paperback, 1994.

---, Dream Boy [1995] New York, Scribner, 1997.

---, Comfort and Joy [1999], Chapel Hill, NC, Algonquin Books, 2003.

---, Jesus Is Sending You This Message, New York, Alyson Books, 2008.

HERMAN, Judith, Trauma and Recovery: The Aftermath of Violence-from Domestic Abuse to Political Terror [1992], New York, BasicBooks (Perseus), 1997.

JARRAWAY, David R., “'Divided Moment' yet ‘One Flesh': The ‘Queer’ Contours of American Gothic Today," Gothic Studies, 2000, April 2 (1): 90-103.

KRISTEVA, Julia, Pouvoirs de l'horreur, Paris, Seuil, 1983.

MADDEN, Ed, “Dream Boy: Jim Grimsley's Gothic Gospel," North Carolina Literary Review, 2000: 9, 111-29.

MAGISTRALE, Tony, Abject Terrors: Surveying the Modern and Postmodern Horror Film, New York, Peter Lang, 2005.

MOERS, Ellen, Literary Women [1976], London, Women's Press, 1978.

MORRISON, Toni, Beloved, London, Picador, 1987.

---, Playing in the Dark: Whiteness and the Literary Imagination [1992], New York, Vintage, 1993.

MULVEY, Laura, Death at $24 x$ a Second: Stillness and the Moving Image [2006], London, Reaktion Books, 2007.

NAYLOR, Gloria, Mama Day [1988], New York, Vintage, 1993.

O'NAN, Stewart, The Night Country [2003], London, Bloomsbury Paperbacks, 2005.

PARKIN-GOUNELAS, Ruth, “Anachrony and Anatopia: Spectres of Marx, Derrida, and Gothic Fiction," in Ghosts: Deconstruction, Psychoanalysis, History, Peter Buse and Andrew Stott eds, New York, MacMillan, 1999, 127-43.

RUFF, Matt, Set This House in Order, New York, HarperCollins, 2003.

SMITH, Ali, Hotel World [2001], New York, Anchor Books, 2002.

SPOONER, Catherine, Contemporary Gothic, London, Reaktion Books, 2006.

WILLIAMS, Anne, Art of Darkness: A Poetics of Gothic, Chicago, UP of Chicago, 1995. 


\section{Films Quoted}

Donnie Darko, dir. Richard Kelly, Pandora, 2001.

Hide and Seek, dir. John Polson, Twentieth Century Fox, 2005.

Identity, dir. James Mangold, Columbia, 2003.

Jacket (The), dir. John Maybury, Warner Bros, 2005.

Jacob's Ladder, dir. Adrian Lyne, TriStar, 1990.

Life Before Her Eyes(The), dir. Vadim Perelman, Magnolia, 2007.

Manchurian Candidate (The), dir. Jonathan Demme, Paramount, 2004.

Mysterious Skin, dir. Gregg Araki, Tartan, 2004.

Nightmare on Elm Street, dir. Wes Craven, New Line, 1984.

Others (The) (2001), dir. Alejandro Almenábar, Dimension Films, 2001.

Pan's Labyrinth [El Laberinto del fauno], dir. Guillermo Del Toro, Warner Bros, 2006.

Paranormal Activity, dir. Oren Peli, Paramount, 2007.

Psycho, dir. Alfred Hitchcock, Paramount, 1960.

Rocky Horror Picture Show (The), dir. Jim Sharman, Twentieth Century Fox, 1975.

Secret Window, dir. David Koepp, Columbia, 2004.

Shining (The), dir. Stanley Kubrick, Warner Bros, 1980.

Shutter Island, dir. Martin Scorsese, Paramount, 2010.

Sixth Sense (The), dir. M. Night Shyamalan, Buena Vista, 1999.

Vanilla Sky, dir. Cameron Crowe, Paramount, 2001.

Waltz With Bashir [Vals Im Bashir], dir. Ari Folman, Sony, 2008.

What Lies Beneath, dir. Robert Zemeckis, Twentieth Century Fox, 2000.

\section{NOTES}

1. Take the virtual tour of Disneyland's Haunted Mansion :

http://www.youtube.com/watch?v=E60nt-_f6Sw

Or of the Tower of Terror (The Hollywood Tower Hotel) at Disneyland Paris :

http://www.youtube.com/watch?v=q7BvY4ZSbyQ

2. http://www.hauntedamericatours.com/toptenhaunted/toptenhauntedhouses/

3. The word house is always in pale blue ink inside the text, as opposed to the black used for most of the text, thus "ghosting" it in print.

4. For an analysis of the aesthetics of trauma, in American literature spanning from Charles Brockden Brown to Paul Auster, see Amfreville, 2009.

5. Maria Beville's study Gothic-Postmodernism (2009) distinguishes postmodern Gothic, particularly as defined by Catherine Spooner (2006, 23-30), in all of its incarnations, from the most aesthetic to the most commercial (in fashion, in rock star images, in low-quality horror film, etc) from Gothic-Postmodernism as philosophical discourse on our contemporary condition (in Derrida, Baudrillard, Lyotard). Gothic-Postmodernism, Beville concludes, "intimates the sublime unimaginable ; otherness, infinity, and reality through terror." (211). She argues that gothic texts 
in the postmodern era thus provide some measure of catharsis of the "terrors of the dissolution and reality and subjectivity that lie at the heart of the postmodern condition" (200), in a form of "Gothic sublime" around a "spirit of terror" (200). Other theorists of contemporary Gothic, like Dani Cavallaro, put the emphasis bluntly on Gothic's reversal of Humanist values (such as the completeness of self seen as illusion and/or abjection) as resonating with the postmodern condition, and with postmodern art: "the Gothic vision foregrounds the need to face up to incompleteness as a condition that may not and must not be redeemed. Phobia, horror and abjection lie with apparent fullness and fulfillment, not with the gap, for plenitude is only ever a broken promise, while the gap is a precondition of creativity." (Cavallaro, 2002, 63). Beville, Spooner and Cavallaro all draw upon "hauntology", the pun on "ontology" that translates Derrida's analysis of being and of History as haunted, in Spectres of Marx (1993).

6. See Amfreville, 2000.

7. "124" (the number of the house, on Bluestone Road) appears at the beginning of each of the novel's three parts, from the liminal image "124 was spiteful. Full of a baby's venom," to the variation "124 was loud," to the final anaphora "124 was quiet." From the initial ghostly presence, a "pool of pulsing red light" that submerges those who enter the house in "a wave of grief" (9), to the clamor of the dead surrounding the house once Beloved has come back in the flesh ("The people of the broken necks, of fire-cooked blood... What a roaring," 181), to the painful absence once Beloved has been chased away by the living ("Nothing. A bleak and minus nothing", 270), the collective trauma of rememory cannot be distinguished from the haunting of 124. Just as the two main characters, Paul D and Sethe, are reunited in the house at the beginning of the novel, so, after having been separated by the ghost, are they reunited under the same roof at the end, in an image that conflates their selves, bodies, and narratives under the same "house" of fiction; but the epilogue and its lament point not to a final epitaph so much as to a continued haunting of the reader by the pain of those "disremembered and unaccounted for" whom the book is dedicated to.

8. The heart of Beloved from which the voice of the dead child rises in italics and fragmentation, in a palimpsest of awful images of the Middle Passage ("I am Beloved and she is mine"), performs the ghostly repossession of this erased collective memory, and "embodies" the shattered, traumatized connection to the dead on the "Other Side."

9. This is precisely why feminist criticism of the late 1970s and of the 1980s focused on women's gothic narratives, in particular, as a taboo-breaking form of exposure of and resistance to patriarchal power. Ellen Moers coined the term "female gothic" in her study Literary Women (1976), and Sandra Gilbert and Susan Gubar's collection of essays The Madwoman in the Attic (1979) reread tales of haunting and/or of female madness as tales of female rage against the oppressive norms of late nineteenth society. Haunted houses became metonymies for the haunted psyche and body, and beyond, for the dark frustrations experienced by women as women, but also as marginalized or repressed artists. As a symbol of possession, the haunted house saw its meaning literally upset as it was turned into a deliberately flaunted representation of the subconscious, within a critique of gender and class politics. Dani Cavallaro points to this having been present in Gothic literature from the outset: "In using outlandish castles and maze-like mansions, narratives of darkness challenge the bourgeois ideal of the sheltering house. Buildings, then, become ways of commenting on class politics, gender politics, and related structures of power and knowledge. They often depict, more or less elliptically, the spaces disavowed by entire cultures. A haunted house is the site/sight upon which collective anxieties converge." (86)

10. For a wide-ranging study of haunted house horror films, see Curtis, 2009.

11. To see the poster : http://www.imdb.com/media/rm1405984000/tt0309698

Last consulted January 13, 2013.

12. See Freyd 24-27 on the debate as to whether dissociation and repression can be combined, and on "amnesia," "repression" and "dissociation" all being forms of "knowledge isolation" that 
protect the psyche from overwhelming pain during and after trauma. Also see Judith Herman on the abused child's defense mechanisms through which "the abuse is [...] walled off from conscious awareness and memory" (Herman, 102)_"walled off" being an image in which the haunted house image significantly returns.

13. More generally, thrillers about amnesia or other forms of memory loss tend to portray the psyche as being the haunted house in and of itself : Richard Kelly's Donnie Darko (2001), Cameron Crowe's Vanilla Sky (2001), Marc Forster's Stay (2005) or Vadim Perelman's The Life Before Her Eyes (2007) all play on the obsessive repetition of entire scenes, warped chronologies, and lurid colors, using either accelerated footage, frozen or arrested images, and seemingly "incoherent" montage to convey a borderline state between reason and madness. In all of these films, however, the line turns out to be that between life and death-a dilation of the moments in which the "haunted" grasps that he or she is dying, and that this "haunting" is in fact his or her ghosting.

14. What Lies Beneath (2000), the Robert Zemeckis thriller in which Michelle Pfeiffer realizes she lives in a house haunted by a victim of male violence, or John Polson's Hide and Seek (2005), play on the same themes. The recent TV series American Horror Story (Ryan Murphy and Brad Falchuk, Fox 2011- ) is an interesting variation on this too.

15. David Koepp's Secret Window (2004), starring Johnny Depp, also plays on this theme.

16. The 1990s were the years in which Judith Butler was deconstructing gender as performance, ten years after Susan Jeffords's analysis of Reagan-era action-heroes as phallic "hardbodies."

17. See in particular Badley, 1995, 44-49.

18. Although one hopes of course that the majority of readers have no such personal history, reading Jennifer J. Freyd (1996) is helpful to understanding how severe trauma can lead to neartotal or even total amnesia. An excellent film built around repressed memories of childhood abuse is Gregg Araki's 2004 adaptation of Scott Heim's Mysterious Skin. War can, of course, produce the same sort of post-traumatic shutting-out of memories: viewers of Ari Folman's Waltz With Bashir (2008) on an Israeli veteran's amnesia concerning the 1982 invasion of Lebanon will recall the shock the film ends on, as the repressed memories return with full force, breaking through the graphics of animated film to archival footage of both personal and collective memory: the horrors of the Sabra and Shatila massacre.

19. See "House of Stairs" (1951) http://www.worldofescher.com/gallery/A23.html and "High and Low" (1947) http://www.worldofescher.com/gallery/A22.html (last consulted November 10, 2010)

20. According to Granofsky, the trauma narrative is one of collective trauma (nuclear disaster, end-of-the world scripts, ecological catastrophe narratives, etc.), as opposed to the narrative of trauma, which is individual. It is often a "waking nightmare" narrative : "A utopian or dystopian setting, in fact, is often used as a starting point, or less often, a terminus in the trauma novel, whose protagonist may find himself or herself in a waking nightmare, or propelled suddenly into paradise, or simply acting a part in an alternate world. [...] Where the dystopian writer tends toward realism or allegory or satire in terms of fictional mode, the trauma novelist uses symbolism as the primary technique." (Granofsky, 1995, 4)

21. Shape-shifting is of course, like the haunted house, the ghost, the double or doppelgänger, or the evil father, a fundamental Gothic trope (see Beville, 2009, 171); one recently rejuvenated in the HBO series True Blood (Alan Ball, HBO, 2008- ).

22. Quoted in Badley, 1995, 11.

23. See Madden (2000) and Jarraway (2000).

24. To see the many versions of the Biblical text : http://bible.cc/john/14-2.htm

25. Also referred to as dissociative identity disorder.

26. One recent exception in cinema is Guillermo del Toro's El Laberinto del Fauno (Pan's Labyrinth, 2006), in its depiction of the maze as inhabited by Pan rather than the Minotaur; although it is a 
place of trials for the little girl who enters it, it is redefined as the underground world of beauty, truth, and resistance to the "outer" world of triumphant fascism and adult sadism.

27. The book cover for House of Leaves plays on this image too: http://www.amazon.fr/HouseLeaves-Mark-Z-Danielewski/dp/0375703764/ref=sr_1_1?ie=UTF8\&s=english-

books\&qid=1289645292\&sr=1-1

(last consulted 10 Nov 2010)

28. The onomastics of "Truant" of course play on his being AWOL or "absent without leave," in a pun on the title.

29. Although the runaway hit Paranormal Activity (2007) is a minor horror film in comparison with Danielewski's masterpiece, it plays on similar ambiguities: haunted houses point to demonic selves.

30. See Spooner $(2006,43)$ for an analysis of how the "mock gothic" of the novel extends into a music album, Haunted, recorded by Danielewski's sister, who goes by the stage name of Poe.

31. The pervasiveness of cinema in popular culture makes it almost impossible for contemporary authors not to allude to film and to mimic cinematographic techniques, whether satirically or straightforwardly. Thus, Stewart O'Nan's dark comedy/ psychological thriller The Night Country (2003), a novel that both plays on clichés associated with ghosts and rejuvenates them, also uses the cinematic technique of the rewind. The novel is narrated by one of a group of teenagers who died in a car crash at midnight on Halloween exactly a year earlier, and who have come to haunt the survivors (the entire novel takes place over 24 hours). After the actual climax of the novel, in the last chapter ironically entitled "Return of the Living"-the cinematic rewind effectively (and lyrically) provides us with a happy end which is in fact the happy beginning (the moment before the accident): “BUT WAIT, DON'T GO YET. Come back with us, before all this begins. Stick the leaves back on the trees, glue the acorns back in place. Use your magic tape to reconstruct us the way Brooks never could. Come on, it won't take long. It'll be easy. Start at the cemetery [...] the priest speaks backwards. Flowers leap into mourners' hands like souvenirs..." (O'Nan, 227-29)

32. American novelist Jennifer Egan's clever novel The Keep (2006) does cast a haunted hotel in fascinating post-modern metatextual ambiguity, but does not use Ali Smith's ghosting of words themselves; I hope I will be forgiven for this detour out of the USA, by way of Scotland, home to a rich Gothic tradition of its own.

33. Hamlet, II, 2, 1.192.

34. See Spooner, 2006, 23, on gothic always having been self-aware, and self-parodic, since Walpole.

\section{RÉSUMÉS}

La maison hantée demeure une figure centrale du cinéma et de la littérature américaine d'aujourd'hui. Ces récits gothiques contemporains sont conscients que la maison hantée est le psychisme lui-même : ce motif hante tant les romans que les films mettant en scène le «moi hanté » de personnages ayant survécu au traumatisme. Ces œuvres se structurent souvent autour de l'image du labyrinthe, qui traduit le sentiment d'aliénation et de terreur ressenti par les personnages, mais permet aussi, dans un jeu réflexif, au film ou au texte de jouer sur sa propre construction comme maison hantée faite d'images et/ou de mots, dans une mise en abyme de la hantise et de la spectralité. 
Haunted houses are still a central figure in contemporary American film and literature alike. Contemporary narratives of haunting are acutely aware that the haunted house is the psyche itself: the motif has become prevalent in postmodern narratives staging the "haunted self" of survivors of trauma. These Gothic texts or films often stage maze imagery that simultaneously captures the characters' feelings of terror and alienation, and Gothic postmodern texts' complexity, playing on their status as "haunted houses" of images and/or words, and, in an ultimate gothic twist, on the "ghosting" of the text itself.

\section{INDEX}

Mots-clés : Ali Smith, dissociation, gothique, Jim Grimsley, labyrinthe, maisons hantées, Mark Z. Danielewski, Matt Ruff, personnalités multiples, postmoderne, projection, spectral, thriller, Toni Morrison, trauma

Keywords : Ali Smith, dissociation, ghosting, Gothic, haunted houses, Jim Grimsley, Mark Z. Danielewski, Matt Ruff, maze, multiple selves, postmodern, projection, thriller, Toni Morrison, trauma

\section{AUTEUR}

\section{MONICA MICHLIN}

Paris-Sorbonne 